\title{
Pengaruh Mind Mapping Terhadap Hasil Belajar Mahasiswi Dalam Mata Kuliah Asuhan Masa Nifas Pada Prodi Kebidanan
}

\author{
Anieq Mumthi'ah Al Kautzarl, Nurfaizah Alza ${ }^{2}$ \\ 1,2 Program Studi DIII Kebidanan, Fakultas Kedokteran dan Ilmu Kesehatan, Universitas Islam \\ Negeri Alauddin Makassar \\ Email: anieq.mumthiah@uin-alauddin.ac.id, nurfaizahalza30@gmail.com
}

\begin{abstract}
ABSTRAK
Latar belakang: Hasil belajar sangat penting dalam dunia pendidikan karena merupakan indikator pencapaian target yang direncanakan. Dalam pembelajaran Asuhan Masa Nifas dibutuhkan pemahaman yang menyeluruh bagi mahasiswi. Model dan metode pembelajaran sangat berperan untuk memaksimalkan tercapainya tujuan pembelajaran. Mind mapping sebagai salah satu metode pembelajaran inovatif yang diharapkan dapat melibatkan mahasiswa untuk secara aktif dalam pembelajaran, menyenangkan dan menarik sehingga dapat meningkatkan konsentrasi dan daya ingat Tujuan : untuk mengetahui pengaruh penerapan mind mapping terhadap hasil belajar mahasiswi dalam mata kuliah Asuhan Masa Nifas pada Prodi Kebidanan.

Metode : Metode penelitian yang digunakan adalah quasi experiment dengan teknik total sampling, jumlah sampel 74 responden. Analisis yang digunakan adalah paired t test dan independent t test.

Hasil : Hasil penelitian menunjukkan terdapat peningkatan bermakna rata - rata nilai hasil belajar antara pre test dan post test pada kelompok intervensi sebesar 12,63 dan pada kelompok kontrol sebesar 8,93 dengan $p$ value $0,000(p<0,05)$. Terdapat perbedaan yang bermakna rata-rata nilai hasil belajar antara kelompok intervensi dan kontrol sebesar 3,70 dengan $p$ value $0,000(p<0,05)$ sehingga dapat disimpulkan bahwa mind mapping berpengaruh terhadap hasil belajar mahasiswi dalam mata kuliah Asuhan Masa Nifas.
\end{abstract}

Kata Kunci: Mind mapping, Hasil Belajar, Asuhan Masa Nifas

\begin{abstract}
Background: Learning outcomes are very important in the world of education because they are indicators of the achievement of planned targets. On learning of postnatal care is a comprehensive understanding is needed for female students. Models and methods of learning are very important for maximizing the achievement of learning goals. Mind mapping as one of the innovative learning methods that is expected to involve students to actively engage in learning, fun and interesting so as to improve concentration and memory.

Purpose: to find out the effect of the application of mind mapping on the learning outcomes of students in the postnatal care of nursing study.

Method: The research method used is quasi experiment with total sampling technique, the sample number of 74 respondents. The analysis used is paired t test and independent t test.

Results: The results showed a meaningful increase in the average learning outcome between pretest and posttest in the intervention group by 12.63 and in the control group by 8.93 with a $p$ value of $0.000(p<0.05)$. There is a meaningful difference in the average learning outcome value between the intervention and control group of 3.70 with $a p$ value of $0.000(p<0.05)$ so it can be concluded that mind mapping affects the learning outcomes of students in the postnatal care course.
\end{abstract}

Keywords: Mind mapping, Learning Outcomes, postnatal care 


\section{PENDAHULUAN}

Bidan adalah tenaga medis terdidik yang mempunyai peran dalam meningkatkan standar kesehatan masyarakat. Dalam menyiapakan bidan yang tanggap terhadap situasi terkini dan dapat mengatasi berbagai situasi kompleks yang dihadapi perempuan, dibutuhkan bidan yang mampu berpikir kritis, analisis sintesis, advokasi dan kepemimpinan yang hanya dapat dihasilkan oleh sistem pendidikan yang berkualitas dan mampu berkembang sesuai kebutuhan zaman. Tenaga bidan yang berkualitas dihasilkan oleh institusi pendidikan kebidanan yang dikelola dengan memperhatikan perkembangan ilmu pengetahuan, teknologi dan regulasi. (1)

Hasil belajar berkaitan dengan pencapaian dalam memperoleh kemampuan sesuai dengan tujuan khusus yang direncanakan. Dengan demikian, tugas utama guru dalam kegiatan ini adalah merancang kegiatan pembelajaran termasuk metode, media belajar, instrument dan lain- lain. ${ }^{(2)}$ Dalam hal ini strategi dan metode pengajaran merupakan salah satu komponen di dalam sistem pembelajaran, tidak dapat dipisahkan dari komponen lain yang dipengaruhi oleh faktor-faktor antara lain tujuan pembelajaran, materi ajar, peserta didik, fasilitas, waktu dan guru atau tenaga pengajar. (3)

Buzan tahun 2012 menjelaskan bahwa mind mapping merupakan cara mencatat yang kreatif, efektif dan secara harfiah akan memetakan pikiran. Mind mapping adalah teknik mencatat yang menggunakan kata-kata, warna, garis, simbol serta gambar dengan memadukan dan mengembangkan potensi kerja otak yang memudahkan seseorang untuk mengatur dan mengingat segala bentuk informasi.

$$
\text { (4) }
$$

Penelitian Ying et al tahun 2017 menunjukkan bahwa kinerja siswa yang ditunjukkan dengan hasil akhir pada kursus farmakologi menunjukkan bahwa kelompok intervensi atau kelompok yang menggunakan mind mapping lebih unggul dibandingkan dengan kelompok kontrol yang hanya menggunakan strategi belajar yang biasa.

Hasil belajar sebagian besar siswa mengalami peningkatan, visualisasi pengetahuan dari pemetaan pikiran atau mind map meningkatkan motivasi siswa untuk bertanya dan menguasai kurikulum inti sehingga berdampak pada peningkatan pengetahuan. (6)

Pada prodi Kebidanan Fakultas Kedokteran dan Ilmu Kesehatan telah dilakukan upaya untuk meningkatkan kualitas pendidikan kebidanan dengan berkonsentrasi pada proses pembelajaran setiap mata kuliah, secara khusus adalah pembelajaran dalam kelas. Dari beberapa banyak materi mata kuliah yang diajarkan, mata kuliah asuhan masa nifas merupakan salah satu diantaranya. Asuhan kebidanan pada masa nifas dan menyusui merupakan bagian dari kompetensi utama seorang bidan. Masa nifas dan menyusui merupakan komponen dalam daur hidup siklus reproduksi seorang perempuan. Bidan mempunyai peran penting dalam memfasilitasi dan memberikan asuhan yang aman dan efektif, memberikan 
pendidikan kesehatan dan konseling serta melakukan penatalaksanaan asuhan kebidanan. (7)

Berdasarkan hasil wawancara terhadap beberapa mahasiswi kebidanan, metode pembelajaran konvensional pada mata kuliah asuhan masa nifas tidak maksimal disebabkan oleh beberapa faktor. Hanya sebagian siswa yang mampu memahami apa yang disampaikan oleh dosen bersangkutan, terkesan membosankan karena mahasiswa kebanyakan mendengarkan dan cenderung pasif dalam proses perkuliahan berlangsung sementara banyak materi yang harus dikuasai sehingga umunya mereka sulit untuk mengingat terlebih mereka juga harus menguasai materi mata kuliah lain.

Berdasar pada temuan tersebut, tentu saja kreativitas dosen sebagai pengajar dibutuhkan untuk mengolah permasalahan yang ada dan menciptakan solusinya. Maka dari hasil analisis, dapat dismpulkan bahwa metode pembelajaran konvensional tidak cukup efektif dan efisien untuk diterapkan dalam proses mata kuliah asuhan masa nifas. Artinya, diperlukan suatu penerapan metode baru yang dapat mengoptimalkan kemampuan mahasiswa secara merata untuk memahami mata kuliah asuhan masa nifas dengan keterbatasan waktu yang ada.
Dari uraian diatas maka peneliti tertarik untuk melakukan penelitian untuk mengetahui pengaruh penerapan mind mapping terhadap hasil belajar mahasiswi dalam mata kuliah Asuhan Masa Nifas pada Prodi Kebidanan.

\section{METODE}

Penelitian ini merupakan penelitian quasi experiment atau eksperimen semu dengan menggunakan rancangan pretest dan posttest nonequivalent kontrol group. Populasi pada penelitian ini adalah seluruh mahasiswi kebidanan semester III tahun ajaran 2018/2019 yang berjumlah 74 orang yang terdiri dari kelas A dan B. Teknik pengambilan sampel yang digunakan adalah total sampling yaitu sebanyak 74 orang.

Analisis data yang digunakan adalah pada analisis univariat kedua kelompok menggunakan distribusi frekuensi dan presentase untuk data yang berskala kategorik sedangkan untuk data yang berskala numerik menggunakan mean dan standar deviasi. Untuk analisis bivariate uji statistik yang akan dilakukan adalah uji statistik paired t test (berpasangan) dan uji statistik independent $t$ test (tidak berpasangan) .

\section{HASIL}

Tabel 1. Distribusi Frekuensi Karakteristik Responden

\begin{tabular}{lcc}
\hline Karakteristik & $\mathrm{n}$ & $\%$ \\
\hline Asal Daerah : & 59 & $79,7 \%$ \\
Sulawesi Selatan & 1 & $1,4 \%$ \\
Sulawesi Tengah & 1 & $1,4 \%$ \\
Sulawesi Tenggara & 1 & $1,4 \%$ \\
Jawa Tengah & 1 & $1,4 \%$ \\
Jawa Timur &
\end{tabular}




\begin{tabular}{lcc}
\hline Karakteristik & $\mathrm{n}$ & $\%$ \\
\hline Maluku & 2 & $2,7 \%$ \\
$\quad$ Nusa Tenggara Barat & 9 & $12,2 \%$ \\
Tingkat Pendidikan Orang Tua & & \\
Ayah & & \\
$\quad$ Tinggi & 45 & $60,8 \%$ \\
$\quad$ Rendah & 29 & $39,2 \%$ \\
Ibu Ninggi & & \\
$\quad$ Rendah & 43 & $58,1 \%$ \\
$\quad 31$ & $49,1 \%$ \\
\hline
\end{tabular}

Tabel 1 menunjukkan bahwa sebagian besar responden berasal dari provinsi Sulawesi Selatan $(79,7 \%)$ dengan tingkat pendidikan orang tua terbanyak berpendidikan tinggi yaitu ayah $(60,8 \%)$ dan ibu $(58,1 \%)$.

Tabel 2. Uji Normalitas Data Hasil Belajar Pretest dan Posttest pada Kelompok Intervensi dan Kontrol

\begin{tabular}{ccc}
\hline \multirow{2}{*}{ Hasil Belajar } & \multicolumn{2}{c}{$p$ value } \\
\cline { 2 - 3 } & Intervensi & Kontrol \\
\hline Pretest & 0,195 & 0,360 \\
Posttest & 0,186 & 0,190 \\
\hline
\end{tabular}

Tabel 2 menampilkan hasil uji normalitas data hasil belajar sebelum dan setelah perlakuan pada kelompok intervensi dan kelompok kontrol, menyatakan bahwa hasil belajar sebelum dan setelah perlakuan pada kedua kelompok berdistribusi normal. Hal ini menunjukkan bahwa dapat menggunakan uji statistik paired $t$ test (berpasangan) dan independent t test (tidak berpasangan).

Tabel 3. Hasil Belajar Pretest dan Posttest pada Kelompok Intervensi dan Kontrol

\begin{tabular}{ccrrr}
\hline \multirow{2}{*}{ Kelompok } & Pretest & Posttest & \multirow{2}{*}{$95 \%$ CI } & \multirow{2}{*}{$p$} \\
\cline { 2 - 3 } & Mean \pm SD & Mean \pm SD & & \\
\hline Intervensi & $65,31 \pm 4,71$ & $77,94 \pm 4,87$ & $11,301-13,969$ & $0,000^{*}$ \\
Kontrol & $66,15 \pm 5,15$ & $75,08 \pm 5,09$ & $7,574-10,290$ & $0,000^{*}$ \\
\hline
\end{tabular}

* paired t test

Tabel 3 di atas menunjukkan bahwa pada kelompok intervensi terdapat peningkatan rata-rata hasil belajar antara pretest dan posttest lebih besar pada kelompok intervensi dibandingkan dengan kelompok kontrol, secara statistik antara rata-rata skor hasil belajar pretest dan posttest pada kelompok intervensi dan kontyrol bermakna

Tabel 4. Perbedaan Hasil Belajar Antara Kelompok Intervensi dan Kontrol

\begin{tabular}{cccc}
\hline Kelompok & Mean \pm SD & $95 \% C I$ & $p$ \\
\hline Intervensi & $12,63 \pm 4,00$ & $1,831-5,574$ & $0,000^{*}$ \\
Kontrol & $8,93 \pm 4,07$ & & \\
\hline
\end{tabular}

* independent $t$ test 
Tabel 4 menunjukkan bahwa terdapat perbedaan rata-rata skor hasil belajar pada kelompok intervensi dan kontrol sebesar 3,70 dengan $p$ value sebesar 0,000 ( $p<0,05), 95 \% C I$ adalah 1,831 hingga 5, 574. Perbedaan tersebut signifikan secara statistic dan dapat disimpulkan bahwa mind mapping berpengaruh terhadap hasil belajar mahasiswi kebidanan dalam Mata Kuliah Asuhan Masa Nifas

\section{PEMBAHASAN}

Analisis hasil belajar antara pretest dan posttest pada kelompok intervensi dan kontrol menunjukkan bahwa pada kelompok intervensi terdapat peningkatan yang pesat dengan rata-rata skor hasil belajar sebesar 12,63 dan peningkatan tersebut bermakna secara statistik dengan $p$ value $0,000(p<0,05)$ sementara pada kelompok kontrol juga mengalami peningkatan tetapi peningkatannya lebih kecil yaitu sebesar 8,93 dengan $p$ value $0,092(p<0,05)$ Hal ini sejalan dengan penelitian Ying $d k k$ Tahun 2017 di China yang menunjukkan kinerja siswa pada kelompok intervensi atau kelompok yang menggunakan mind mapping lebih unggul dibandingkan dengan kelompok kontrol yang hanya menggunakan strategi belajar yang biasa. (8) Penelitian Leliavia $d k k$ tahun 2017 pada siswa kelas VII SMPN Tempunak juga menyatakan bahwa penerapan mind mapping menunjukkan hasil belajar yang lebih tinggi dibandingkan dengan dua metode pembelajaran yang lainnya. ${ }^{(8)}$

Hasil penelitian ini sesuai pula dengan penelitian oleh Lombanturoan dan Juanda tahun 2015 yang melakukan penelitian pada siswa kelas X SMK Negeri 1 Lintongnihuta semester genap Tahun Ajaran 2014/2015 yang berjumlah 30 siswa untuk kelas eksperimen dan 30 siswa kelas kontrol. Dari hasil penelitian ditemukan bahwa model pembelajaran mind mapping memberikan hasil belajar yang berbeda dibandingkan dengan pembelajaran konvensional terhadap hasil belajar Ilmu Bahan Bangunan siswa kelas X Program Keahlian Kontruksi Batu Beton SMK Negeri 1 Lintongnihuta, Tahun Ajaran 2014/2015. Model pembelajaran mind mapping memberikan pengaruh yang lebih tinggi yaitu 7,138 dibandingkan dengan pembelajaran konvensional sebesar 1,689. Hasil penelitian ini didukung pula dengan dengan hasil yang didapatkan Liu dkk tahun 2014 bahwa mind mapping memberikan pengaruh positif terhadap proses pembelajaran dan pengajaran, termasuk pengaruh terhadap pencapaian atau hasil belajar.

Pada penelitian ini terjadi peningkatan rata-rata hasil belajar yang signifikan pada kelompok intervensi karena pengaruh dari metode pembelajaran mind mapping yang interaktif dibandingkan dengan kelompok kontrol. Hal ini disebabkan karena dengan penerapan mind mapping adalah strategi pembelajaran yang mengupayakan setiap peserta didik untuk menggali ide-ide kreatif dan aktif dalam mengikuti kegiatan pembelajaran dengan membuat gambargambar dan garis yang berwarna-warni agar lebih mudah untuk dihafal sehingga pembelajaran yang dilakukan akan menjadi lebih hidup, variatif dan membiasakan peserta didik memecahkan permasalahan dengan cara 
memaksimalkan daya pikir dan kreativitas serta dapat membantu peserta menjadi lebih mandiri. (10)

Mind mapping dapat mengoptimalkan kedua fungsi otak sehingga dapat berpikir dan mengingat dengan lebih baik dan efektif. Mind mapping juga memiliki sifat dinamis, natural dan dirancang untuk memudahkan kerja otak secara cepat dan efisien.

Salah satu teknik mencatat yang dapat menyimpan informasi dan lebih mudah diingat adalah mind mapping dibandingkan dengan menggunakan teknik mencatat tradisional.

Sari $d d k$ tahun 2016 mengungkapkan bahwa data tanggapan guru yang diperoleh melalui metode wawancara terhadap model mind mapping yang telah dilaksanakan, menyebutkan bahwa model pembelajaran ini mampu meningkatkan partisipasi aktif siswa dalam proses pembelajaran. Model pembelajaran mind mapping mampu memicu rasa ingin tahu siswa, membangun keterampilan sosial siswa saat berkelompok, meningkatkan keterampilan berpendapat dan berbicara di depan umum, serta berusaha mencari dan menggali informasi untuk mendapatkan konsep yang benar dalam materi pembelajaran. Penggunaan teknik mind mapping mampu menambah partisipasi aktif siswa dalam pembelajaran dan mendukung pemahaman siswa.

Pembelajaran konvensional merupakan pembelajaran biasa yang paling sering dilakukan oleh guru-guru di sekolah. Pada pembelajaran ini guru memberikan penerangan atau penuturan secara lisan kepada sejumlah siswa. Siswa mendengarkan dan mencatat seperlunya. Pada umumnya siswa bersifat pasif, yaitu menerima apa saja yang dijelaskan oleh guru. Berdasarkan hal tersebut model konvensional berpotensi untuk membuat siswa menjadi bosan saat proses belajar berlangsung dan dengan sendirinya akan menurunkan minat belajar siswa. ${ }^{(13)}$

Menurut Wulandari $d k k$ tahun 2012, mind mapping adalah cara mencatat yang kreatif, efektif, dan memetakan pikiranpikiran kita, secara menarik, mudah dan berdaya guna. (14) Berbanding terbalik dengan metode konvensional, seperti yang dikemukakan oleh Dermayoga $d k k$ tahun 2013 bahwa proses pembelajaran hanya terfokus pada pengembangan aspek kognitif siswa. Ini terlihat dari cara guru melaksanakan proses pembelajaran yang hanya terfokus pada buku, dan pelajari materi sampai habis. Siswa sangat jarang diberikan kesempatan untuk berfikir kritis untuk menemukan masalah, dan memberikan pendapat dari pengetahuan berfikirnya sendiri. Siswa terlihat kurang memiliki minat untuk belajar. Dengan tidak adanya minat belajar maka guru sulit untuk mentransfer materi yang ingin dipelajari. (15)

\section{KESIMPULAN}

Perubahan skor nilai hasil belajar mahasiswi kebidanan dalam Mata Kuliah Asuhan Masa Nifas yang diberikan mind mapping lebih besar daripada dengan yang tidak diberikan mind mapping dan dapat disimpulkan bahwa Terdapat pengaruh mind mapping terhadap nilai hasil belajar mahasiswi kebidanan dalam Mata Kuliah Asuhan Masa Nifas. 


\section{DAFTAR PUSTAKA}

1. Kemenkes RI. Kurikulum Inti Pendidikan DIII Kebidanan. Jakarta: Kemenkes RI; 2011.

2. Desriana D, Ashar A, Djamaluddin H. Perbandingan Hasil Belajar Siswa Menggunakan Medias Pembelajaran Berbasis Lingkungan Dengan Media Internet dalam Pembelajaran Asma Basa di Man Indapuri. J IPA dan Pembelajaran IPA JIPI. 2018;2(1):50-5.

3. Danasasmita W. Pentingnya Strategi dan Metode Pembelajaran dalam Kegiatan Belajar Mengajar. Bandung: JURUSAN PENDIDIKAN BAHASA JEPANG FAKULTAS PENDIDIKAN BAHASA DAN SENI UNIVERSITAS PENDIDIKANINDONESIA; 2009.

4. Buzan T. Buku Pintar Mind Map. Jakarta: PT. Gramedia Pustaka Utama; 2012.

5. Ying G, Jianping X, Haiyun L, Xia L, Jianyu Y, Qun X, et al. Using mind maps to improve medical student performance in a Pharmacology Course at Kumming Medica University. J Coll Physicians Surg Pak. 2017;27(7):404-8.

6. Stokhof H, Vries B de, Bastiaens T, Martens R. Using Mind Maps to Make Student Questioning Effective: Learning Outcomes of a Principle-Based Scenario for Teacher Guidance. Res Sci Educ. 2018;50:203-225.

7. Wahyuningsih, Puji. H. Bahan Ajar Kebidanan Asuhan Kebidanan Nifas dan Menyusui. Jakarta: Kementerian Kesehatan Republik Indonesia; 2018.

8. Leliavia, Al-Muhdhar MHI, Suwono H. Pengaruh Penerapan Pembelajaran Arias Dipadu Mind Map Terhadap Hasil Belajar Kognitif Siswa Kelas VII. J Pendidik. 2017;2(4):569-74.

9. Liu Y, Guiqing Z, Guozhen M, Yuwei B. The effect of mind mapping on teaching and learning: a meta-analysis. Stand J Educ Essay. 2014;2(1):017-31.

10. Nurani IW, Wakidi, Yustina SE. Pengaruh Model Pembelajaran Mind Mapping Terhadap Hasil Belajar Sejarah Siswa. PESAGI (Jurnal Pendidik dan Penelit Sejarah). 2014;2(2).

11. Wati ML, Siswati. Pengaruh Metode Mind Map Terhadap Peningkatan Hasil Belajar Mata Pelajaran Ilmu Pengetahuan Alam Terpadu pada Siswa Kelas VII. J Empati. 2015;4(4):131-8.

12. Sari EN, Ridlo. S, Nur RU. Pengaruh Model Pembelajaran Discovery Learning dengan Mind Mapping Terhadap Hasil Belajar Siswa pada Materi Sel di SMA Negeri 1 Salatiga. Unnes Sci Educ J. 2016;5(3).

13. Wahyuniawati. Kefektifan Model Kontekstual untuk Meningkatkan Keterampilan Menulis Narasi (Studi Eksperimen pada Siswa Kelas VIII SMP Negeri 1 Kebasen Tahun 2012) [Internet]. UNIVERSITAS MUHAMMADIYAH PURWOKERTO; 2013. Available from: http://repository.ump.ac.id/5943/

14. Wulandari T, Sutijan, Kartono. Penerapan Metode Mind Mapping Untuk Meningkatkan Pemahaman Konsep Tanah dan Batuan. J Didakt Dwija Indria. 2014;2(7).

15. Dermayoga W, Wawan L, Marhaeni. Pengaruh Implementasi Mind Mapping Terhadap Hasil Belajar IPS Ditinjau dari Minat Siswa Kelas IV SD Sathya Sai Denpasar. E-Journal Progr Pascasarj Univ Pendidik Ganesha. 2013;3. 